\title{
Pengaruh Pendekatan Jelajah Alam Sekitar (JAS) Terhadap Keterampilan Proses dan Hasil Belajar Biologi Siswa Kelas X SMA Negeri 5 Lubuklinggau
}

\author{
Dian Samitra, Mareta Widiya, Nurwita Dwi Rahmasari \\ Progam Studi Pendidikan Biologi, FKIP, STKIP-PGRI Lubuklinggau \\ JL. Mayor Toha Tabapinggin Lubuklinggau \\ surat elektronik: dian.samitra@gmail.com
}

\begin{abstract}
ABSTRAK
Penelitian ini bertujuan untuk mengetahui pengaruh pendekatan Jelajah Alam Sekitar (JAS) terhadap keterampilan proses dan hasil belajar biologi siswa kelas X. Penelitian ini dilaksanakan di SMA Negeri 5 Lubuklinggau tahun ajaran 20I5/2016. Jenis penelitian ini adalah eksperimen dengan populasi siswa kelas X yang terdiri dari 9 kelas. Sampel adalah siswa kelas X.I sebagai kelas eksperimen dan kelas X.8 sebagai kelas kontrol. Teknik pengumpulan data yang digunakan adalah observasi melalui lembar observasi dan tes tertulis berbentuk uraian sebanyak 9 butir soal Pengambilan data observasi dilakukan sebanyak satu kali. Data keterampiplan siswa dianalisis dengan cara deskriptif kualitatif, sedangkan hasil belajar dianalisis dengan menggunakan uji-t. Untuk keterampilan proses, rata-rata keseluruhan aspek keterampilan proses siswa menggunakan pendekatan Jelajah Alam Sekitar (JAS) yaitu 76,I I \% dengan kategori baik sedangkan aspek keterampilan proses pada kelas kontrol berkategori kurang dengan persentase $56,77 \%$. Berdasarkan nilai ratarata tes awal kelas eksperimen 45,7I, nilai rata-rata tes akhir 72,I6. Nilai rata-rata tes awal pada kelas kontrol adalah 45,86 dan nilai rata-rata tes akhir adalah 6I,40. Berdasarkan hasil perhitungan uji-t mengenai data psostes siswa menunjukkan bahwa thitung $>$ ttabel $(3,52>$ I,67). Hal ini berarti pendekatan Jelajah Alam Sekitar (JAS) berpengaruh terhadap keterampilan proses dan hasil belajar biologi siswa kelas X SMA Negeri 5 Lubuklinggau.
\end{abstract}

Kata kunci: pendekatan jelajah alam sekitar (JAS), keterampilan proses, hasil belajar

\section{Pendahuluan}

Pada dasarnya kegiatan belajar dilakukan untuk membangun pemahaman dan makna. Untuk membangun makna dan pemahaman yang tinggi kegiatan pembelajaran tidak boleh monoton dan pasif, apalagi jika dalam pembelajaran biologi. Seharusnya tidak hanya sebatas konsep-konsep yang abstrak, tetapi juga mampu mengembangkan keaktifan siswa. Hingga saat ini, umumnya proses pembelajaran di dalam kelas diarahkan kepada kemampuan siswa untuk menghafal informasi, sehingga siswa dipaksa untuk mengingat dan menyimpan berbagai informasi yang diperoleh tanpa dituntut untuk memahami informasi yang diingatnya (Sanjaya, 20I4:I I) Padahal belajar bukanlah hanya sekedar proses menghafal ataupun mengingat.

Sejauh ini pembelajaran biologi masih didominasi oleh kondisi dimana guru menjadi fokus sumber belajar dan metode ceramah merupakan pilihan utama guru dalam kegiatan belajar, sehingga pembelajaran ditekankan pada hasil belajar pada aspek kognitif bukan pada kemampuan siswa untuk mengusai proses. Hal ini terjadi karena guru merasa memiliki tanggung jawab kepada masyarakat yaitu mencetak lulusan dengan nilai yang bagus (Mulyani, et al, 2008:8-9; Rusmiyati, et al, 2009:75 )

Dalam proses pembelajaran IPA di sekolah khususnya biologi, seharusnya siswa sangat ditekankan belajar melalui alam sekitar seperti: menjelajahi dan memahami alam secara ilmiah, dengan adanya kegiatan pembelajaran tersebut diharapkan dapat melibatkan siswa dalam menemukan konsep melalui hasil pengamatan secara langsung dan memberikan efek positif bagi siswa dalam mengembangkan berbagai kompetensi yang dimiliki (BSNP, 2006:377). Kegiatan pembelajaran yang dilakukan dengan berbagai aktivitas di alam tentunya melibatkan aspek keterampilan proses siswa untuk merekonstruksi pemahaman konseptualnya melalui kegiatan eksplorasi, seperti: mengamati, mengumpulan data, membandingkan,, memprediksi, membuat pertanyaan, merancang kegiatan, membuat hipotesis dan membuat laporan secara komprehensif ( $\mathrm{Naf}$ anudiniyah, et al, 2013:172).

Penerapan keterampilan proses dalam pembelajaran biologi dapat dilaksanakan melalui kegiatan pendekatan pembelajaran khusus agar keterampilan siswa terus berkembang. Salah satu pendekatan pembelajaran yang mendukung keadaan tersebut yaitu pembelajaran melalui Pendekatan Jelajah Alam Sekitar (JAS) (Yuniastuti, 20I3:3I-32).

Pendekatan Jelajah Alam Sekitar (JAS) telah menjadi strategi pembelajaran sejak tahun 2005 (Ridlo, et al 2012:I). Pendekatan jelajah alam sekitar (JAS) merupakan pendekatan pembelajaran yang didalam kegiatannya memanfaatkan objek khususnya lingkungan sekitar secara langsung melalui kegiatan pengamatan, diskusi dan laporan hasil (Winarni, 20I3: I45). Pendekatan JAS 
tidak mengharuskan siswa menghafal informasi, tetapi mendorong siswa untuk mengembangkan informasi pengetahuan yang diperoleh berdasarkan konsep biologi melalui proses eksplorasi dan investigasi di lingkungan sekitar mereka.

Pendekatan Jelajah Alam Sekitar (JAS) dapat meningkatkan keterampilan proses dan hasil belajar siswa karena pendekatan pembelajaran ini dianggap cocok diterapkan karena didesain untuk meningkatkan kemandirian dan rasa tanggung jawab siswa terutama pada pembelajaran Biologi (Yuniastuti, 2013:36). Selain itu juga Pendekatan Jelajah Alam Sekitar menuntun siswa untuk dapat belajar dari mengalami dan menemukan sendiri dengan memanfaatkan alam sekitar (Sari et al., 2013:166).

Berdasarkan hasil observasi awal yang dilakukan di SMA Negeri 5 Lubuklinggau, saat kegiatan pembelajaran pada materi yang berhubungan dengan lingkungan misalnya ekosistem, guru menggunakan pembelajaran konvesional yang mengarah pada pendekatan teacher centered yaitu metode ceramah dan berlangsung di dalam kelas saja dan rata-rata hasil belajar siswa belum mencapai tingkat kriteria ketuntasan minimum (KKM) yang ditetapkan sebesar 70. Dari I52 siswa sebanyak 87 siswa (57\%) mencapai KKM dan 65 siswa (43\%) belum mencapai KKM. Padahal SMA Negeri 5 Lubuklinggau memiliki lingkungan sekitaryang mendukung untuk pembelajaran biologi di luar kelas berupa hutan kecil yang masih alami.

Pembelajaran yang dilakukan oleh guru mengarah pada pendekatan teacher centered sehingga selama ini guru tidak melakukan penilaian keterampilan proses kepada siswa. Keterampilan proses hanya dilakukan guru pada saat pengambilan nilai untuk ujian nasional saja. Pendekatan jelajah alam sekitar dapat membentuk pengetahuan siswa lewat kegiatan eksplorasi (Mulyani, et al, 2008:2).

Berdasarkan uraian tersebut maka peneliti melakukan penelitian tentang pengaruh pendekatan Jelajah Alam Sekitar (JAS) terhadap keterampilan proses dan hasil belajar siswa kelas X SMA Negeri 5 Lubuklinggau. Peneliti mengukur keterampilan proses pada aspek mengamati, mengklasifikasikan, memprediksi, mengukur, menyim-pulkan dan mengkomunikasikan, sedangkan hasil belajar yang diukur adalah hasil belajar ranah kognitif.

\section{Metode Penelitian}

Jenis penelitian ini adalah penelitian eksperimen dengan desain yang berbentuk pretest-posttest group atau desain kelompok kontrol-eksperimen. Kelas pertama diberi pengaruh pendekatan Jelajah Alam Sekitar (JAS) sebagai kelompok eksperimen dan kelas kedua sebagai kelompok kontrol. Desain penelitiannya dapat dilihat pada tabel 1 .
Tabel I. Desain Penelitian

\begin{tabular}{cccc}
\hline Kelompok & $\begin{array}{c}\text { Pre- } \\
\text { test }\end{array}$ & Perlakuan & $\begin{array}{c}\text { Post- } \\
\text { test }\end{array}$ \\
\hline Eksperimen (X.I) & $\mathrm{O}_{1}$ & $\mathrm{X}$ & $\mathrm{O}_{2}$ \\
Kontrol (X.8) & $\mathrm{O}_{3}$ & - & $\mathrm{O}_{4}$ \\
\hline
\end{tabular}

Keterangan:

$\mathrm{O}_{\mathrm{I}}$ : Pre-test pada kelas eksperimen

$\mathrm{O}_{3}$ : Pre-test pada kelas kontrol

$\mathrm{X} \quad$ : Treatment (perlakuan)

$\mathrm{O}_{2}$ : Post-test pada kelas ekperimen

$\mathrm{O}_{4} \quad$ : Post-test pada kelas kontrol

Populasi dalam penelitian ini adalah siswa kelas $\mathrm{X}$ SMA Negeri 5 Lubuklinggau tahun pelajaran 2015/2016 yang terdiri dari 9 kelas dan berjumlah 294 siswa. Teknik pengambilan sampel yang digunakan adalah simple random sampling yaitu pengambilan anggota sampel dalam populasi dilakukan secara acak. Sampel yang diambil adalah dua kelas yaitu kelas X.I sebagai kelas Eksperimen menggunakan pendekatan Jelajah Alam Sekitar (JAS), dan X.8 sebagai kelas Kontrol. Perlakuan dilakukan satu kali pertemuan pada materi ekosistem.

Instrumen yang digunakan untuk mengukur keterampilan proses adalah lembar observasi, instrumen observasi dapat dilihat pada tabel 5. Instrumen yang digunakan untuk mengukur hasil belajar adalah soal uraian. Tes yang digunakan untuk mengukur data hasil belajar biologi siswa kelas eksperimen dan kelas kontrol yaitu soal berbentuk uraian berjumlah 9 butir soal. Tes dilakukan sebanyak dua kali pada kelas eksperimen dan kelas kontrol yaitu berupa tes kemampuan awal (pre-test) dan tes kemampuan akhir (post-test). Data yang terkumpul dianalisis dengan uji-t pada taraf signifikan $\alpha=$ 0,05 .

Teknik Analisis data keterampilan proses menggunakan rumus:

$\mathrm{NP}=\times 100 \%$ dengan: $\mathrm{R}=$ (Purwanto, 2012:102)

Keterangan:

NP : Nilai persen keterampilan proses

$\mathrm{R}$ : Skor rata-rata aspek keterampilan proses

SM : Skor maksimum ideal dari aspek keterampilan proses

$\Sigma$ ST : Jumlah skor total dari aspek keterampilan proses

$\mathrm{N}$ : Banyaknya jumlah subjek

Interpretasi nilai persentase keterampilan proses siswa menurut Purwanto (2012:103) terbagai seperti pada tabel 2.

Tabel 2. Interpretasi Nilai Persen Keterampilan Proses

\begin{tabular}{ll}
\hline Nilai & Interpretasi \\
\hline $86 \%<\mathrm{NP} \leq 100 \%$ & Sangat Baik \\
$76 \%<\mathrm{NP} \leq 85 \%$ & Baik \\
$60 \%<\mathrm{NP} \leq 75 \%$ & Cukup \\
$55 \%<\mathrm{NP} \leq 59 \%$ & Kurang \\
$\mathrm{NP} \leq 54 \%$ & Sangat Kurang \\
\hline
\end{tabular}




\section{Hasil dan Pembahasan}

\section{Keterampilan Proses}

Observasi dilakukan di kelas X SMA Negeri 5

Lubuklinggau untuk menganalisis aspek-aspek keterampilan proses siswa. Aspek tersebut adalah aspek mengamati, mengklasifikasikan, memprediksi, meng-ukur, menyimpulkan dan mengkomunikasikan. Pelaksanaan observasi dilakukan satu kali pada setiap siswa dengan menggunakan lembar observasi. Hasil perhitungan lembar observasi keterampilan proses untuk kelas kontrol (tabel 3) dan kelas eksperimen (tabel 4).

Tabel 3. Persentase Keterampilan Proses Siswa Pada Kelas Kontrol (Tanpa Pendekatan Jelajah Alam Sekitar)

\begin{tabular}{clcc}
\hline No & Aspek Keterampilan Proses & Nilai Persen (\%) & Kategori \\
\hline I & Mengamati & $80,47 \%$ & Baik \\
2 & Mengklasifikasikan & $55,47 \%$ & Kurang \\
3 & Memprediksi & $56,25 \%$ & Kurang \\
4 & Mengukur & $45,31 \%$ & Sangat Kurang \\
5 & Menyimpulkan & $56,25 \%$ & Kurang \\
6 & Mengkomunikasikan & $46,88 \%$ & Sangat Kurang \\
\multicolumn{2}{c}{ Rata-rata } & $56,77 \%$ & Kurang \\
\hline
\end{tabular}

Tabel 4. Persentase Keterampilan Proses Siswa Pada Kelas Eksperimen (Pendekatan Jelajah Alam Sekitar)

\begin{tabular}{clcc}
\hline No & Aspek Keterampilan Proses & Nilai Persen (\%) & Kategori \\
\hline I & Mengamati & $91,67 \%$ & Sangat Baik \\
2 & Mengklasifikasikan & $77,50 \%$ & Baik \\
3 & Memprediksi & $69,17 \%$ & Cukup \\
4 & Mengukur & $76,67 \%$ & Baik \\
5 & Menyimpulkan & $63,33 \%$ & Cukup \\
6 & Mengkomunikasikan & $78,33 \%$ & Baik \\
& Rata-rata & $76,11 \%$ & Baik \\
\hline
\end{tabular}

Tabel 5. Instrumen observasi Keterampilan Proses

\begin{tabular}{|c|c|c|c|}
\hline No & Pernyataan & Skor & Kriteria Penskoran \\
\hline I. & $\begin{array}{l}\text { Mengamati } \\
\text { Menuliskan hewan dan tumbuhan yang } \\
\text { diamati }\end{array}$ & $\begin{array}{l}4 \\
3 \\
2 \\
2\end{array}$ & $\begin{array}{l}\text { Jika menuliskan hewan dan tumbuhan masing-masing lebih } \\
\text { dari } 7 \text { jenis (spesies) } \\
\text { Jika menuliskan hewan dan tumbuhan masing-masing } 5-7 \\
\text { jenis (spesies) } \\
\text { Jika menuliskan hewan dan tumbuhan masing-masing } 3-4 \\
\text { jenis (spesies) } \\
\text { Jika menuliskan hewan dan tumbuhan masing-masing I-2 } \\
\text { jenis (spesies) }\end{array}$ \\
\hline 2 & $\begin{array}{l}\text { Mengklasifikasikan } \\
\text { Mengelompokkan komponen biotik } \\
\text { dan abiotik }\end{array}$ & $\begin{array}{l}4 \\
3 \\
2 \\
\mathrm{I}\end{array}$ & $\begin{array}{l}\text { Jika mengelompokkan seluruh komponen biotik dan biotic } \\
\text { Jika mengelompokkan sebagian komponen biotik dan abiotik } \\
\text { Jika mengelompokkan salah satu omponen } \\
\text { Jika tidak melakukan pengelompokkan }\end{array}$ \\
\hline 3 & Memprediksi & $\begin{array}{l}4 \\
3 \\
2 \\
1\end{array}$ & $\begin{array}{l}\text { Jika menuliskan } 3 \text { interaksi dalam ekosistem dengan benar } \\
\text { Jika menuliskan } 2 \text { interaksi dalam ekosistem dengan benar } \\
\text { Jika menuliskan I interaksi dalam ekosistem dengan benar } \\
\text { Jika salah dalam menuliskan contoh }\end{array}$ \\
\hline 4 & $\begin{array}{l}\text { Mengukur } \\
\text { a. Menuliskan hasil pengamatan pada } \\
\text { lembar kerja siswa (LKS) }\end{array}$ & $\begin{array}{l}4 \\
3 \\
2 \\
1\end{array}$ & $\begin{array}{l}\text { Jika menuliskan } 3 \text { indikator pada LKS } \\
\text { Jika menuliskan } 2 \text { indikator pada LKS } \\
\text { Jika menuliskan I indikator pada LKS } \\
\text { Jika tidak menuliskan hasil pengamatan pada LKS }\end{array}$ \\
\hline
\end{tabular}


b. Membedakan antara populasi, komunitas, dan ekosistem

$5 \quad$ Menyimpulkan hasil pengamatan yang telah dilakukan

6 Mengkomunikasikan hasil hasil pengamatan
4 Jika menuliskan pengertian populasi, komunitas, dan ekosistem dengan benar

3 Jika hanya menuliskan dua pengertian dengan benar

2 Jika hanya menuliskan satu pengertian dengan benar

I Jika tidak menuliskan pengertian populasi, komunitas, dan ekosistem atau salah

4 Jika menyimpulkan hasil pengamatan dari 3 indikator

3 Jika menyimpulkan hasil pengamatan dari 2 indikator

2 Jika menyimpulkan hasil hasil pengamatan dari I indikator

I Jika tidak menuliskan kesimpulan

4 Jika menyampaikan hasil pengamatan secara lengkap, jelas, dan sesuai dengan tujuan yang diharapkan

3 Jika menyampaikan hasil pengamatan secara lengkap dan jelas

2 Jika menyampaikan hasil pengamatan dengan jelas

I Jika tidak menyampaikan hasil pengamatan

\section{(diadaptasi dari Purwanto, 20I2)}

Berdasarkan tabel 3 dan tabel 4, dapat dilihat persentase hasil observasi keterampilan proses siswa selama melakukan kegiatan pembelajaran konvensional (Kontrol) dan dengan menggunakan pendekatan Jelajah Alam Sekitar (JAS). Pada tabel 4 menunjukkan bahwa aspek mengamati memperoleh persentase yang dikategorikan sangat baik. Untuk aspek mengklasifikasikan, mengukur, dan mengkomunikasikan memperoleh kategori baik. Sedangkan aspek memprediksi dan menyimpulkan dikategorikan cukup. Jadi, rata-rata aspek keterampilan proses siswa menggunakan pendekatan Jelajah Alam Sekitar dikategorikan baik dengan persentase sebesar 76,II \%. Berbeda dengan tabel 3, menunjukkan bahwa untuk aspek mengamati berkategori baik. Untuk aspek mengklasifikasikan, memprediksi, menyimpulkan berkategori kurang dan aspek mengkomunikasikan dan mengukur memperoleh kategori sangat kurang. Sehingga rata-rata aspek keterampilan proses siswa kelas kontrol berkategori kurang dengan persentase $56,77 \%$. Jadi, rata-rata aspek keterampilan proses siswa dengan menggunakan pendekatan Jelajah Alam Sekitar lebih baik dibandingkan kelas kontrol.

Keterampilan proses siswa pada kelas kontrol tanpa melibatkan siswa untuk belajar di alam, melainkan melalui pengamatan audio visual yang ditampilkan guru melalui infocus. Hal ini menyebabkan siswa kurang dillibatkan dalam penyelidikan secara langsung di lapangan. Berbeda dengan hasil keterampilan proses yang diperoleh melalui pendekatan Jelajah Alam Sekitar tersebut membuktikan bahwa belajar Biologi akan sangat efektif jika siswa melakukan eksplorasi, dan observasi secara langsung di lapangan, karena dengan belajar dengan pendekatan Jelajah Alam Sekitar juga melibatkan beberapa interdisipliner intelektual, fisik, emosional dan mengembangkan keterampilan proses (Higgins et al, 2010:2). Kemudian Henikusniati (2015:2), juga mengemukakan bahwa jika belajar dengan pendekatan Jelajah Alam Sekitar terbiasa dilakukan siswa maka aspek keterampilan proses dalam diri siswa dapat terus berkembang.

\section{Hasil Belajar Siswa}

Pada penelitian data hasil belajar diperoleh daripretest dan posttest. Hasil tes yang telah dilakukan baik di kelas eksperimen dan kelas kontrol dapat dilihat pada tabel 6 .

Tabel 6. Hasil Tes Kelas Eksperimen dan Kontrol

\begin{tabular}{|c|c|c|c|c|c|}
\hline \multirow[t]{2}{*}{ No } & \multirow[t]{2}{*}{ Statistik } & \multicolumn{2}{|c|}{ Eksperimen } & \multicolumn{2}{|c|}{ Kontrol } \\
\hline & & Pre. & Post. & Pre. & Post \\
\hline I & Jml. Siswa & 30 & 30 & 32 & 32 \\
\hline 2 & $\begin{array}{l}\text { Nilai } \\
\text { Terendah }\end{array}$ & 27 & 43 & 25 & 38 \\
\hline 3 & $\begin{array}{l}\text { Nilai } \\
\text { Tertinggi }\end{array}$ & 68 & 88 & 70 & 83 \\
\hline 4 & Rerata & $45,7 \mathrm{I}$ & 72,16 & 45,86 & 61,40 \\
\hline & $\begin{array}{l}\text { ata prete } \\
\text { an dianal } \\
\text { an setelah } \\
\text { omogenita } \\
\text { at yang tel } \\
\text { dan hom } \\
\text { uji-t layal } \\
\text { dan postee }\end{array}$ & $\begin{array}{r}\text { maups } \\
\text { denga } \\
\text { elewati } \\
\text { Berda } \\
\text { dilakul } \\
\text { en sehi } \\
\text { ligunak }\end{array}$ & $\begin{array}{l}\text { post } \\
\text { meng } \\
\text { rasyara } \\
\text { arkan } \\
\text { an, dipe } \\
\text { gga pe } \\
\text { n. Rang } \\
\text { hat pad }\end{array}$ & $\begin{array}{l}\text { yang } \\
\text { akan } \\
\text { aitu uj } \\
\text { ri da } \\
\text { leh dis }\end{array}$ & $\begin{array}{l}\text { diperoleh } \\
\text { iji-t. Uji-t } \\
\text { normalitas } \\
\text {-data uji } \\
\text { ribusi data } \\
\text { ta dengan }\end{array}$ \\
\hline
\end{tabular}

Tabel 7. Hasil Analisis Uji-t Data Pretest dan Posttest

\begin{tabular}{ccccc}
\hline Data & thitung & $\mathrm{dk}$ & tabel & Kesimpulan \\
\hline Pretest & 0,05 & 60 & 2,00 & thitung $<$ tabel; Ho diterima \\
Posttest & 3,52 & 60 & 1,67 & thitung $>$ tabel $;$ Ho ditolak \\
\hline
\end{tabular}

Berdasarkan tabel 6 menunjukkan bahwa hasil analisis uji-t mengenai kemampuan akhir menunjukkan bahwa thitung $>$ trabel $(3,52>$ I,67). Jadi, hasil belajar biologi siswa yang diajarkan dengan menggunakan pendekatan Jelajah Alam Sekitar (JAS) lebih baik daripada hasil belajar siswa pada kelas kontrol atau dengan kata lain ada pengaruh pendekatan jelajah alam 
sekitar terhadap hasil belajar siswa. Hasil analisis data post-test terdapat perbedaan hasil belajar antara kelas eksperimen dan kelas kontrol. Hal tersebut disebabkan oleh perlakuan yang diberikan pada kelas eksperimen yaitu proses pembelajaran dengan menggunakan pendekatan Jelajah Alam Sekitar (JAS) dan dilaksanakan di luar kelas. Sehingga diperoleh nilai rata-rata 72,I6 dan kelas kontrol tanpa perlakuan diperoleh nilai ratarata 61,40. Dengan demikian, nilai rata-rata hasil posttest kelas eksperimen lebih tinggi dibandingkan dengan kelas kontrol.

Berdasarkan hasil penelitian yang dilakukan pada kelas X SMA Negeri 5 Lubuklinggau, Hasil belajar siswa pada kelas eksperimen lebih tinggi dari kelas kontrol dikarenakan pada kelas eksperimen siswa belajar dengan pendekatan JAS. Kemampuan belajar tersebut sangat dipengaruhi oleh keterampilan proses yang dilakukan oleh siswa, karena melibatkan keterampilan kognitif, manual dan sosial. Konsep belajar dengan keadaan dimana siswa dikaitkan dengan lingkungan alam sekitar, sehingga dapat mempermudah siswa dalam mempelajari materi dan menjadikan hasil belajarnya menjadi lebih bermanfaat (Sugiyo et.al., 2008: 236243). Selain itu, selama beberapa tahun terakhir perkembangan proses belajar harus terus berbenah demi kualitas pendidikan yang lebih baik. Praktik pembelajaran yang biasa dilakukan di dalam kelas tampaknya tak bisa dilakukan jika konsep yang dipelajari semestinya beralih ke proses pembelajaran yang dilakukan secara outdoor. Piaget juga mengatakan bahwa lingkungan akan memaksa pikiran siswa agar dapat mengasimilasi informasi baru yang diterimanya (Simatwa, 2010:37I). Kegiatan pembelajaran yang dilakukan di luar ruangan yang berhubungan langsungdengan alam bebas mampu menciptakan proses pembelajaran yang tidak terbatas dan sering digunakan sebagai sarana pembelajaran informal dan nonformal.Kegiatan belajar yang didorong secara bekerja sama di dalam kelompok mampu memberikan manfaat dalam peningkatan keterampilan berfikir dan memaksa siswa untuk terus bertukar pendapat dan berkolaborasi dalam belajar (Dumont et al., 2012:10).

\section{Simpulan}

Berdasarkan judul dan tujuan penelitian dapat disimpulkan bahwa pendekatan Jelajah Alam Sekitar (JAS) berpengaruh terhadap keterampilan proses dan hasil belajar biologi siswa kelas X SMA Negeri 5 Lubuklinggau.

\section{Daftar Pustaka}

Badan Standar Nasional Pendidikan (BSNP). 2006. Peraturan Menteri Pendidikan Nasional Republik Indonesia Nomor 22 Tahun 2006. Jakarta: BSNP

Dumont, Hanna, David Istance \& F. Benavides. 2012. The Nature of Learning: using research to ins pire practice. Pratitioner Guide From Centre for Educational research and Innovation Article. OECD Publishing.

Henikusniati. 2015. Penerapan Pembelajaran dengan Pendekatan Keterampilan Proses Sains untuk Meningkatkan Hasil Belajar Kimia SMK Negeri 3 Mataram. BIOTA Vol. VIII. No I Juni 20I5: 37 42 Mataram: IAIN Mataram.

Higgins, Peter, Robbie Nicol, Simon Beames, Beth Christie \& Roger Scrutton. 2010. Education and Culture Committee Outdoor Learning. Learning and Teaching Scotland p. 6 University of Edinburgh.

Mulyani, E.S., Marianti, A., Kartijono, N. E., Widianti, T., Saptono, S., Pukan, K. K.,Bintari, S.H. 2008. Jelajah Alam Sekitar (JAS) Pendekatan Pembelajaran Biologi. Semarang. Jurusan Biologi FMIPA UNNES.

Mulyani, Sri, A. Marianti, Nugroho Edi K., Tuti W., Sigit S., Krispinus K. Pukan, Siti H., 2008. Jelajah Alam Sekitar (JAS) Pendekatan Pembelajaran Biologi. Semarang :Universitas Negeri Semarang.

Nafanudiniyah, Raksun Ahmad \& Mertha I Gde. Efektivitas Pembelajaran Kooperatif dengan Pendekatan Jelajah Alam Sekitar (JAS) Kelas VIII di SMP Negeri I Kediri Lombok Barat. Jurnal Kependidikan I2 (2): I7I-I77. Mataram : LPPM IKIP Mataram

Purwanto, N. 2012. Prinsip-prinsip dan Teknik Evaluasi Pengajaran. Bandung: Remaja Rosdakarya.

Ridlo, S \& Andin Irsadi. 2012. Pengembangan Nilai Karakter Konservasi Berbasis Pembelajaran. Jurnal Penelitian Pendidikan. Vol. 29 No. 2 2012: I45$\mathrm{I} 54$.

Rusmiyati, A \& A. Yulianto. 2009. Peningkatan Keterampilan Proses Sains dengan Menerapkan Problem Based-Instruction. Jurnal Pendidikan Fisika Indonesia Vol. 5 Juli 2009.

Sanjaya, W. 2014. Strategi Pembelajaran Berorientasi Standar Proses Pendidikan. Jakarta: Kencana Prenada Media Group.

Sari, Yunita Kartika, Sri Mulyani E S., \& Saiful Ridlo.2013. Efektivitas Penerapan Metode Quantum Teaching Pada Pendekatan Jelajah Alam Sekitar (JAS) Berbasis Karakter dan Konservasi. Journal of Biology Education Vol. 2 No. 2 September 2013.: I65-I72. Semarang:Unnes.

Simatwa, Enose M. W. 2010. Piaget's theory of intellectual development and itsimplication for instructional management at presecondary school 
level. Academic Journals. Educational Research and Reviews Vol. 5 No. 7. Juli 2010: 366-37I.

Sugiyo, Warlan, Latifah \& Zaenal Abidin. 2008. Peningkatan Hasil Belajar Siswa dengan Model Pembelajaran Team Game Tournament Melalui Pendekatan Jelajah Alam Sekitar dan Penilaian Portofolio. Jurnal Inovasi Pendidikan Kimia Vol. No. I. Januari 2008: 236-243. Semarang:Unnes.

Winarni, Endang Widi. 2013. Perbandingan Sikap Peduli Lingkungan, Keterampilan Proses dan Pemahaman Konsep antara Siswa Pada Pembelajaran IPA Menggunakan Pendekatan Jelajah Alam Sekitar (JAS) dan Ekspositori di Sekolah Dasar. Jurnal IImiah PGSD Vol.V No.I April 2013:145 Jakarta:UNJ.

Yuniastuti, E. 2013. Upaya Meningkatkan Keterampilan Proses dan Hasil Belajar Biologi dengan Pendekatan Pembelajaran Jelajah Alam Sekitar pada Siswa Kelas VII SMP Kartika V-I Balikpapan. Jurnal Ilmu-Ilmu Sosial, Vol. 5 No. I Februari 2013: 3I38. Kalimantan: Kopertis Wilayah II. 